\title{
Az Európai Zöld Megállapodás és a 2021-2027-es többéves pénzügyi keret kapcsolata
}

\section{The Interrelation between the European Green Deal and the Multiannual Financial Framework 2021-2027}

A fenntarthatóság komplex kérdésköre, ezen belül is az éghajlatváltozással kapcsolatban nemrég meghirdetett úgynevezett „klímavészhelyzet” számos kihivást jelent az Európai Unió számára. A tanulmány arra vállalkozik, hogy bemutassa a 20212027-es többéves pénzügyi keret és a klímasemlegesség finanszirozásának kérdéseit, összefüggéseit az Európai Unióban. A kérdés kiindulópontjának a jelenlegi Európai Bizottság által kidolgozott, az EU „kizöldítésére” vonatkozó stratégia, az Európai Zöld Megállapodás és a klímafinanszírozással összefüggésben közzétett Igazságos Átmenet Mechanizmus keretrendszere tekinthetö. A tanulmány dokumentumelemzéssel mutatja be, hogy az Európai Uniónak jelenleg milyen stratégiai javaslatai vannak a 2050-re kitüzött klímasemlegesség eléréséhez, majd kvantitativ módszerrel is alátámasztjuk, hogy a Brexit mellett a fenntarthatóság finanszírozásának kérdése is döntő befolyást gyakorol a jelenleg tárgyalás alatt álló hétéves költségvetésre.

Kulcsszavak: Európai Unió, Európai Zöld Megállapodás, Igazságos Átmenet Mechanizmus, klímasemlegesség finanszírozása, többéves pénzügyi keret 2021-2027

Sustainability and global warming pose a number of challenges for the European Union. The aim of this paper is to present the current issues and connections between the 2021-2027 Multiannual Financial Framework and the financing of climate neutrality in the European Union. The two main strategies related to this topic are the current long-term strategy of the European Commission called European Green Deal, and the recently published Just Transition Mechanism in the context of climate finance. The methodology of the study is document analysis showing what current

Horváth Klaudia Gabriella doktoranduszhallgató, Nemzeti Közszolgálati Egyetem Közigazgatástudományi Doktori Iskola. E-mail: horvath.klaudia.gabriella@gmail.com 
strategic proposals of the European Union have to achieve climate neutrality by 2050, and with a quantitative method I also support the hypothesis that in addition to Brexit, sustainability funding has a decisive impact on the EU's next budget.

Keywords: European Union, European Green Deal, Just Transition Mechanism, climate neutrality financing, 2021-2027 Multiannual Financial Framework

\section{Bevezetés és a vizsgálat módszere}

A hamarosan már csak huszonhét tagállamból álló Európai Unió politikai és gazdasági befolyása vitatathatatlanul meghatározó a 21. században zajló nemzetközi folyamatokra. Ebből következően a fenntarthatóság komplex kérdéskörének, ezen belül is az éghajlatváltozással kapcsolatban nemrég meghirdetett úgynevezett „klímavészhelyzet” kihívásaira világos, gyakorlati és mindenekelőtt hatásos válaszlépések kialakítására van szükség az unió részéről.

A fenntarthatóság manapság gyakran használt, divatos fogalom. A tanulmánynak ugyan nem célja a kifejezés definiálása, azonban fontos tisztáznunk, hogy egy rendkívül komplex kérdéskörről van szó. A fenntarthatóság átfogja a környezeti, a társadalmi és a gazdasági alrendszereket, a fogalom alapvető lényege, hogy a gazdasági fejlődés, a környezet védelme és a szociális, humán tényezők egyfajta egyensúlyának megvalósítására törekszik a jövő nemzedékéért tett felelősségvállalás mellett. ${ }^{1} \mathrm{Az}$ EU és tagállamai számos nemzetközi eseményen, konferencián és az ENSZ-en belül is aktívan hozzájárulnak a fenntarthatóságról szóló párbeszédhez. (Lightfoot-Burchell 2005) A fenntartható fejlődéssel kapcsolatos kérdések pedig már a korábbi években is megjelentek különböző stratégiai dokumentumokban, EU-s és nemzeti szintû akcióprogramokban, valamint gyakorlati jelleggel az EU környezetvédelmi és más szakpolitikai szabályozásában is. (Baranyai-Csernus, 2019:118-148) Példának okáért megemlíthetőek az 1973 óta elfogadott környezetvédelmi cselekvési programok - jelenleg a hetedik program² végrehajtása zajlik -, az Európai műanyag stratégia (Európai Bizottság, 2018c), a 2005-ben létrehozott kibocsátás-kereskedelmi rendszer ${ }^{3}$ vagy a hulladékgazdálkodással és levegőminőség-védelemmel kapcsolatos irányelvek. ${ }^{4}$ Jól látható tehát, hogy az Európai Unió

A fenntarthatóság fogalmáról bővebben lásd: (Baranyai-Csernus, 2019; Knoll-Lakatos, 2014)

Az Európai Parlament és a Tanács 2013. november 20-i 1386/2013/EU határozata a „Jólét bolygónk felélése nélkül” című, a 2020-ig tartó időszakra szóló általános uniós környezetvédelmi cselekvési programról. Elérhető: https://eur-lex.europa.eu/legal-content/HU/TXT/HTML/?uri=CELEX:32013 D1386\&from=EN (A letöltés dátuma: 2020. 04. 10.)

3 Az Európai Parlament és a Tanács 2003. október 13-i 2003/87/EK irányelve az üvegházhatást okozó gázok kibocsátási egységei Közösségen belüli kereskedelmi rendszerének létrehozásáról és a 96/61/EK tanácsi irányelv módosításáról. Elérhető: https://eur-lex.europa.eu/LexUriServ/LexUriServ.do?uri=CONSLEG:2003L0087:20041113:HU:PDF (A letöltés dátuma: 2020. 04. 10.)

4 Az Európai Parlament és a Tanács 2008. november 19-i 2008/98/EK irányelve a hulladékokról és egyes irányelvek hatályon kívül helyezéséről. Elérhető: https://eur-lex.europa.eu/legal-content/ HU/TXT/?uri=celex:32008L0098 (A letöltés dátuma: 2020. 04. 10.); Az Európai Parlament és a Tanács 2008. május 21-i 2008/50/EK irányelve a környezeti levegő minőségéről és a Tisztább levegőt Európának elnevezésű programról. Elérhető: https://eur-lex.europa.eu/legal-content/HU/TXT/HTML/?uri=CELEX:32008L0050\&from=hu (A letöltés dátuma: 2020. 04. 10.) 
sosem volt közömbös a fenntarthatóság okozta kihívásokat illetően, az azonban megállapítható, hogy nem minden közösségi kezdeményezésből lett sikertörténet, illetve a környezetvédelem mint komplex jelenség nagyon széles, a gazdasághoz és a szociális biztonsághoz ezer szállal kötődő szabályozási terület.

A tanulmány ezzel összefüggésben primer források, elsősorban stratégiai dokumentumok - kiemelten a European Green Deal (Európai Zöld Megállapodás) és a Just Transition Mechanism (Igazságos Átmenet Mechanizmus) bizottsági közlemények -, EU-s programok, jogszabályok és sajtóközlemények alapján mutatja be a fenntarthatóság témakörének megjelenését az Európai Unió jelenlegi politikájában. A tanulmány célja, hogy az olvasó világos képet kapjon a több száz oldalnyi dokumentum és hangzatos sajtóközlemények által közvetített, társadalmi és környezeti fenntarthatósággal kapcsolatos kérdésekről és megoldási lehetőségekről. Emellett a tanulmányban arra igyekszünk rávilágítani, hogy a fenntarthatóság kérdése az EU-ban elválaszthatatlanul összefonódik a 2021-2027-es többéves pénzügyi keret tárgyalásaival. Utóbbi problémakörrel kapcsolatban elemezzük a költségvetési tárgyalások jelenlegi állását és legutóbbi fejleményeit, valamint érintőlegesen a Brexit hatásait is.

A kutatásunk elsősorban kvalitatív jellegú, dokumentumelemzésen alapul. A fent említett jogszabályok, stratégiai dokumentumok és sajtóközlemények elsősorban angol nyelven érhetőek el. Ezek segítségével elemezzük a Bizottság fő stratégiájában, az Európai Zöld Megállapodásban foglalt terveket, azonosítjuk a fenntarthatóság és klímafinanszírozás legfőbb kérdéseit az Európai Unióban. A 2021-2027-es többéves pénzügyi keret vizsgálata során felvázoljuk a tárgyalások jelenlegi állását, a továbbhaladás lehetőségeit és a fenntarthatósággal kapcsolatos tagállami aggályokat. A költségvetés és az Igazságos Átmenet Mechanizmus összefüggéseit kvantitatív módszerrel is vizsgáljuk. A tagállami allokációk és az egy főre jutó támogatások összevetésével - kutatásunk szerint - kimutatható, hogy a Bizottság egyes tagállamoknak kedvez, amely engedmények a költségvetési tárgyalások során akár a koalíciós csoportok átrendeződéséhez is vezethetnek.

A fentiekkel összhangban tanulmányunk kutatási kérdése tehát, hogy a fenntarthatóság és klímasemlegesség finanszírozása - az új Bizottság fent említett stratégiáit elemezve - milyen hatást gyakorol az új többéves pénzügyi keret tárgyalásaira.

\section{Ursula von der Leyen bizottsága és a Green Deal}

A Jean-Claude Junckert váltó Ursula von der Leyen által elnökölt új Európai Bizottság a vártnál csak később kezdhette meg munkáját. Az egyes portfóliók biztosjelölti meghallgatásának elhúzódása miatt 2019. december 1-jétôl lépett hivatalba az új biztosi kollégium. A korábbiakhoz képest magas részvétellel zajló 2019. májusi európai parlamenti választások után politikai és kompromisszumos alkuk sorozata vezetett az EU új első embereinek kiválasztásához. A német védelmi minisztérium éléről átigazolt von der Leyen a Bizottság első női elnöke. Jelöltként már programtervében (úgynevezett politikai iránymutatásaiban) igen ambiciózus célokat tűzött ki, vezető szerepet szánva Európának a fenntarthatóság, környezetvédelem, digitalizáció és szociális piacgazdaság területén. (Európai Bizottság, 2019a) Az elnök korábbi ígéretéhez híven, az Európai Zöld Megállapodás című stratégiai dokumentumot valóban bemutatták a Bizottság 
működésének első száz napjában, a tagállamok részéről azonban vegyes fogadtatásban részesült. (Barbière, 2019)

Mivel az új Európai Parlament a Bizottság elnökének megválasztását ahhoz kötötte, hogy a kollégium mutasson erős európai klíma- és környezetvédelmi ambíciót a szakpolitikák területén, egyértelmű volt, hogy az Európai Zöld Megállapodás minden szakpolitikában irányadó alapvetéseket fog lefektetni. A bizottsági közlemény 2019. december 11-én jelent meg, amelyet az egy nappal később kezdődő európai tanácsi csúcson az állam- és kormányfők is megvitattak, majd az Európai Tanács elfogadta következtetéseit a 2050-es klímasemlegesség eléréséről. (Európai Tanács, 2019)

Az Európai Zöld Megállapodás nem egy részletes jogalkotási csomag, inkább egyfajta ötletgyưjtemény és menetrend, tematikus célok alá rendezve, a konkrét megvalósítási lehetőségeket tehát nem részletezi. A dokumentum nagyban épít a meglévő EU-s környezetvédelmi jellegú stratégiákra, amelyeknek a felülvizsgálatát, jogszabályok esetében pedig azok módosítását, szigorítását vetíti előre. Az Európai Zöld Megállapodásban rögzített legfontosabb pontok a következők:

1. Tiszta, megfizethető és biztonságos energiaellátás

- javaslat az első európai éghajlat-politikai jogszabályról (úgynevezett „klímatörvény");

- az importált fogyasztási cikkek “karbonadóztatására” vonatkozó javaslat;

- az energiaigényes iparágak további dekarbonizációjának elősegítése;

- az energiaszegénység kezelése;

- intelligens energia-infrastruktúra kialakítása.

2. Az ipar mozgósítása a környezetbarát és körforgásos gazdaság érdekében

- a hulladék csökkentése fenntartható temékpolitikával („ökodizájn”);

- újrahasznosítható, tartós és javítható termékek ösztönzése;

- a fenntartható és munkahelyteremtéssel járó gazdasági tevékenységek bővítése;

- technológiafejleszés.

3. Energia- és erőforrás-hatékony építés és korszerűsítés

- köz- és magánépületek korszerúsítési programjának beindítása;

- az épületek energiahatékonyságának elősegítése közösségi finanszírozással.

4. A fenntartható és intelligens mobilitásra való átállás felgyorsítása

- a multimodális szállítás fejlesztése (a közúti forgalom átterelése vasútra és belvízi szállítási utakra);

- alternatív üzemanyagok gyártásának és forgalmazásának támogatása;

- a belső égésű motorok kibocsátási előírásainak fokozása;

- az energiaadó-irányelv felülvizsgálata (előreláthatólag egyes üzemanyagok adómentességének megszüntetése).

5. A termelőtől a fogyasztóig: méltányos, egészséges és környezetbarát élelmiszerrendszer kialakítása

- a közös agrárpolitika (KAP) ökologizálása;

Ursula von der Leyen as a candidate for the president of the European Commission (2019): Political Guidelines for the Next European Commission 2019 - 2024. https://ec.europa.eu/commission/sites/betapolitical/files/political-guidelines-next-commission_en.pdf (A letöltés dátuma: 2020. 04. 10.) 
- a fogyasztók megfelelőbb tájékoztatása;

- az élelmiszer-pazarlás csökkentése.

6. Az ökoszisztémák és a biológiai sokféleség megóvása és helyreállítása

- az erdészeti stratégia felülvizsgálata;

- új biodiverzitási stratégia kidolgozása;

- védett tengeri területek összekapcsoltságának fokozása és e területek megfelelő igazgatása.

7. Szennyezőanyag-mentességi célkitűzés a toxikus anyagoktól mentes környezetért

- levegőre, vízre és talajra vonatkozó szennyezőanyag-mentességi cselekvési terv kidolgozása;

- levegőminőségi standardok felülvizsgálata;

- a kibocsátás-kereskedelmi rendszer reformja (különös tekintettel a légitársaságoknak adott kedvezményekre);

- fenntarthatósági célú vegyi stratégia előterjesztése. (Európai Bizottság, 2019b)

A dokumentum legnagyobb gyengesége, hogy az erős klímapolitikai ambíciók mellé nem rendel hasonlóan ambiciózus finanszírozási lehetőségeket. Lényegében lefekteti, hogy el kell választani a gazdasági növekedési lehetőségeket az erőforrások „túlfogyasztásától” olyan módon, hogy 2050-re az EU klímasemleges legyen. A klímasemlegesség alatt azt értjük, mikor a termékek/szolgáltatások és szervezetek által kibocsátott szén-dioxid és a légkörből visszavont, megkötött üvegházhatású gázok (ÜHG) mennyisége egyenlő. (Murray-Dey, 2009) Ennek értelmében az EU a lehető legkisebbre csökkenti karbonlábnyomát, az ezt követően megmaradt károsanyag kibocsátását pedig zöld projektekkel „ellentételezi”. Ezzel kapcsolatban az Európai Zöld Megállapodás előrevetíti a Modernizációs Alap és Innovációs Alap ${ }^{6}$ megerősítését, valamint körvonalazza az Igazságos Átmenet Mechanizmus létrehozását a fenntarthatósági kihívások finanszírozására. (Európai Bizottság, 2019b) A Bizottság az Európai Zöld Megállapodásban egyértelműen összeköti a modern, erőforrás-hatékony és versenyképes Európa, valamint a polgárainak egészségét és jólétét védő Európa stratégiáját, egyfajta fenntartható szociális piacgazdaságot kialakítva. Mivel azonban az új, 2021-2027-es időszakra vonatkozó többéves pénzügyi keret (Multiannual Financial Framework - MFF) tárgyalásának időszakában vagyunk, a tagállamok biztosítékot várnak arra vonatkozóan, hogy a közösség klímacélkitűzéseinek finanszírozása nem a nemzeti, és méginkább nem a meglévő EU-s pénzügyi alapok rovására valósul meg. Ebből pedig jól érzékelhető, hogy a Bizottság részéről sem teljesen kidolgozott a hangzatos név mögé bújtatott javaslatcsomag, és a tagállamok sem tekintik adottnak a feltételeket jelen keretek között az Európai Zöld Megállapodásban foglalt célok megvalósításához.

Az alapokat 2016-ban hozták létre az EU-s szintủ költséghatékony kibocsátáscsökkentés és az alacsony szén-dioxid-kibocsátású technológiákba történő beruházások növelése érdekében. Az Innovációs Alapban nemzeti borítékokat hoztak létre az EU tíz legalacsonyabb jövedelmű országa számára, a Modernizációs Alap pedig projektalapú támogatási rendszer, amelyre viszont bármely tagállam pályázhat. Mindkét alap célja a tagállami energetikai rendszerek modernizációja és az energiahatékonyság növelése. Lásd: (Cătuți-Elkerbout, 2019; Európai Unió Tanácsa, 2016)

Európai Tükör 2020/1. 


\section{A 2021-2027-es többéves pénzügyi keret (MFF) és a fenntarthatóság}

A többéves pénzügyi keret (MFF) jelenleg hét évre rögzíti az EU kiadásainak felső határait, összesítve és az egyes tevékenységi területekre, alapokra lebontva. Az MFF a kiadásokat tágabb „fejezetekre” bontja, amelyek az egyes uniós prioritásoknak felelnek meg. A 2007-2013 és a jelenleg kifutó 2014-2020-as költségvetés struktúrája hasonlóan alakult. Külön fejezetet alkotott a fenntarthatóság (versenyképesség és kohéziós források) valamint a természeti erőforrások megőrzésére (KAP, halászati politika, környezetvédelem) fordítható előirányzat. Ez a két fejezet átlagosan a közös költségvetés kiadási oldalának 85\%-át adja. A fennmaradó 15\% jellemzően az európai állampolgárság, adminisztrációs költségek és az EU mint globális partner témájú fejezetek között oszlik meg. (Európai Unió Tanácsa, 2013; Boldizsár et al., 2016)

A fenntarthatóság problémakörével kapcsolatban fontos kiemelni, hogy a 20212027-es költségvetés pozitív elmozdulást jelent a 2014-2020-as kerethez képest, mert a jelenlegi tervezetekben rögzítik, hogy a Párizsi Megállapodással összefüggésben vállalt uniós klímacélok megvalósítására az MFF teljes összegének minimum 25\%-a fordítandó. (Európai Unió Tanácsa, 2019) A 2014-2020-as költségvetési időszakban a keret teljes összegének 20\%-át, nagyjából 209,8 billió eurót költöttek a tagállamok hivatalosan a klímasemlegesség feltételeinek megteremtésére. A százalékos arány és az összeg megemeléséről nagyjából konszenzus van az EU intézményei és a tagállamok között is, a kérdés inkább az, hogy a szükséges források milyen fejezetekből csoportosíthatóak át a klímafinanszírozás céljából. (D’Alfonso, 2019)

A fent leírt forráselosztási szerkezetből jól látszik, hogy amennyiben elfogadjuk azt az álláspontot, hogy az EU által kitűzött klímasemlegességi és fenntarthatósági célok megvalósításához valóban egy a mostaninál ambiciózusabb büdzsé szükséges, úgy komoly átalakításra lenne szükség a többéves pénzügyi keret eddigi rendszerében. A költségvetési tárgyalások során nagy vita övezi, hogy a fenntarthatóság finanszírozása melyik fejezetbe, milyen hagyományos politika mellé kerüljön, alkosson-e egyáltalán külön fejezetet. (Erforth-Keijzer, 2020) Míg a tagállamok, azon belül is a 2004-ben csatlakozott, a magországokhoz képest gazdaságilag elmaradott tagállamok, a két nagy szakpolitika, a KAP és kohéziós források megvágását egyöntetűen elutasítják, a fejlett, többségében alapító tagállamok a szociális alapú pénzosztás helyett a versenyképességbe és digitalizációba történő beruházásokat részesítik előnyben. Mindezek mellett nem felejthetjük el, hogy a 2016 óta húzódó, de 2020-ban véglegesedni látszó Brexittel az Egyesült Királyság mint az EU egyik legnagyobb nettó befizetője távozik a közösségből, nem kis lyukat ütve ezzel a költségvetés bevételi oldalán. A tagállamok átlagosan a GNI (bruttó nemzeti jövedelem) körülbelül 1\%-át fizetik be az EU-s költségvetésbe, amely tételek egyben a költségvetés bevételi oldalának nagyjából 69\%-át teszik ki. A bevételek maradék körülbelül 30\%-a, az EU külső határán szedett vámbevételekből (saját forrás), az úgynevezett hozzáadottérték-adóból (áfaalapú forrás) és néhány százalékban egyéb bevételekből folyik be. Ebből a három tételből áll tehát össze a költségvetés bevételi oldala, amelynek szerkezetéből szintén jól látszik, hogy a tagállamok befizetése adja a keret közel háromnegyedét. Mindebből arra következtethetünk, hogy az EU 
hagyományos saját forrásai nem elégségesek, minden tagállam számára elfogadható kompromisszumot kell találni a többéves pénzügyi keretek tárgyalásánál, máskülönben nincs megállapodás. (Palánkai et al., 2011)

Hasonló veszély fenyeget a jelenlegi tárgyalásoknál is, hiszen még mindig nincs megegyezés a tagállamok között. A Brexit miatt még bonyolultabb a kompromisszum elérése, hiszen első körben arról szükséges megállapodni, hogy a kiesett összeget a tagállamok pótolják-e, vagy sem, ${ }^{7}$ valamint arról is, hogy az új kihívásokra - mint a fenntarthatóság vagy a migráció - honnan csoportosíthatnak át forrásokat. Az 1. ábra azt mutatja meg, hogy a tagállamok összes GNI-alapú befizetése százalékos arányban hogyan oszlik meg a többéves pénzügyi keret befizetéseinél. Ebből jól látható, hogy Németország, az Egyesült Királyság és Franciaország abszolút és relatív értelemben is a legnagyobb befizetők, s a Brexittel most egy ilyen tagállam hagyja el a Közösséget.

A fentiekre tekintettel a legegyszerűbb megállapodást valószínúleg úgy lehetne elérni, ha a 2014-2020-as költségvetés főösszegét és szerkezetét megtartanák, korrigálva a Brexit miatt kieső bevétellel úgy, hogy a plusz befizetési kötelezettséget minden tagállam - népességéhez vagy gazdasági fejlettségéhez képest - arányosan viselje. Így lényegében az előző időszakkal nagyjából azonos tagállami részesedést lehetne elérni, amelyről hét évvel ezelőtt már konszenzusos alapon megyegyeztek az állam- és kormányfők. A klímaambíciók mellett elkötelezett, hagymányosan nettó befizető tagállamok azonban kiemelik, hogy a kitűzött klímacélok megvalósításához nem nyújt elegendő forrást a korábbi MFF vonatkozó fejezete, illetve az elmúlt években sokan hangoztatják, hogy a kohéziós pénzek elköltését átláthatóbbá kellene tenni, lehívásukat pedig például jogállamisági kondicionalitáshoz kötni. Emellett a bent maradó nettó befizetők, mint Németország, Dánia vagy a Benelux államok, semmi esetre sem szeretnék a GNI 1\%-a körül mozgó nemzeti befizetésüket növelni. Ha azonban nem növekszik a főösszeg, sőt a Brexit miatt csökken is, a klímacélokra felhasználható, megfelelő mennyiségű összeget csak a hagyományos politikák - KAP és kohézió - rovására lehet átcsoportosítani. Ez pedig az ellenérdekelt oldal, a „kohézió barátai” néven ismert országok számára elfogadhatatlan alternatíva. (Európai Parlament, 2019) Ez utóbbi országcsoport álláspontját az új többéves pénzügyi kerethez jól mutatja, hogy a 2020. februári Európai Tanács csúcstalálkozója után a nevüket Ambiciózus Európa költségvetése elnevezésre változtatták. Ez egyben jelenti azt, hogy a résztvevők nem csupán a kohéziós politika mértékét tartják szem előtt, hanem az egész keretből szeretnének igazságos módon részesülni, másrészt pedig mutatja azt is, hogy a tagok következetesen elfogadhatatlannak tartják a nagy befizetők által ajánlott 1\%-os nemzeti GNI-hozzájárulás szintjét. ${ }^{8}$

Érdemes megjegyeznünk, hogy a költségvetési tárgyalások kezdetekor a tagállamok többsége, és a Juncker vezette Bizottság is amellett foglalt állást, hogy az EU költségvetése csökkenjen NagyBritannia kilépésével. Azonban mivel a költségvetési tárgyalásokról nagyon kevés az információ, és a kompromisszum jelenleg még távolinak tünik, ezt az eshetőséget is érdemes megvizsgálnunk, mert jól szemlélteti a tagállamok költségvetési pozícióit és érdekeit. (Európai Bizottság, 2018a) www.kormany.hu/hu/a-miniszterelnok/hirek/ambiciozus-europahoz-ambiciozus-koltsegvetes-kell (A letöltés dátuma: 2020. 04.10.)

Európai Tükör 2020/1. 


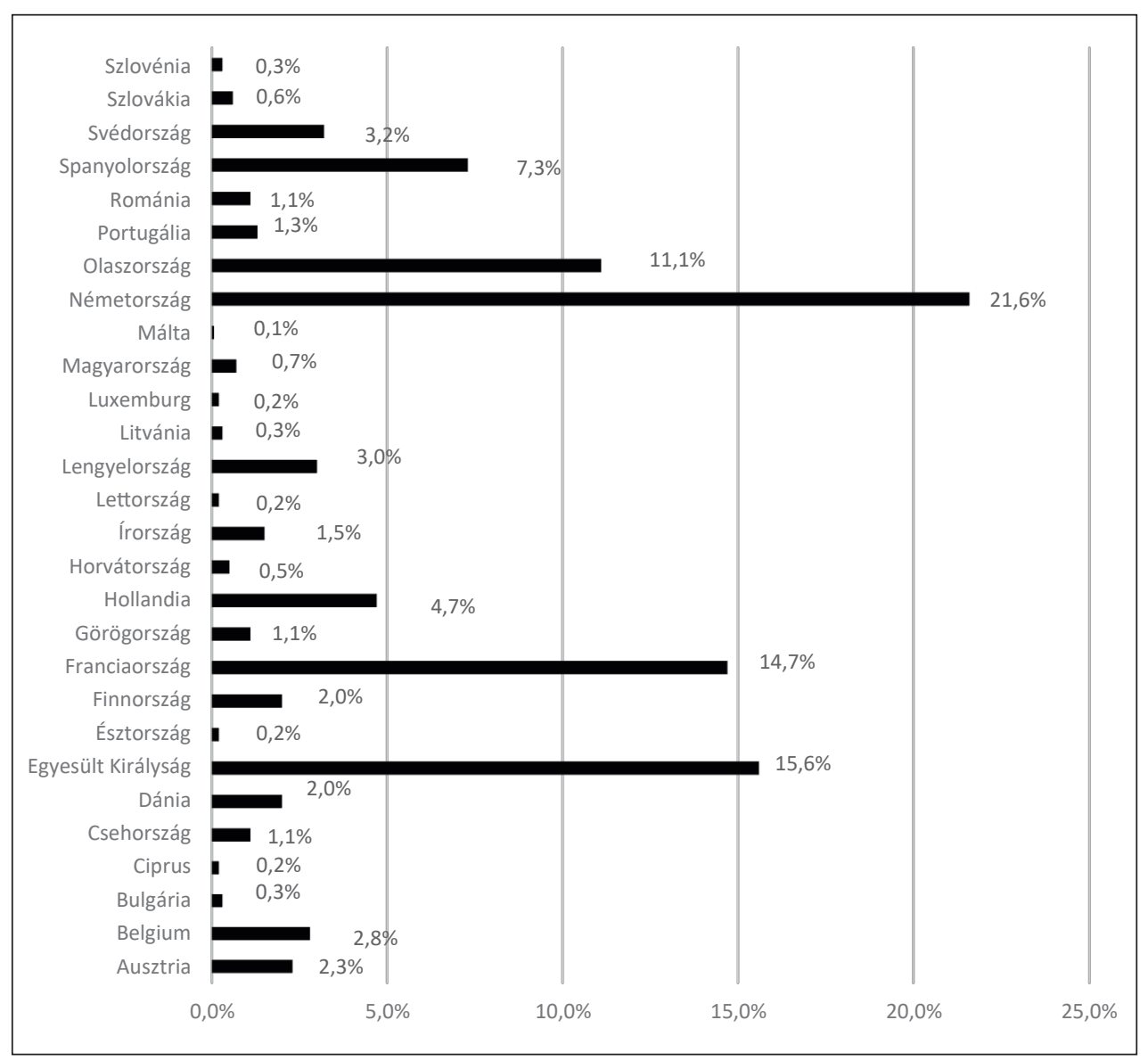

1. ábra

Az EU-tagállamok GNI alapú-befizetéseinek átlagos, százalékos aránya, a 2014-2020-as költségvetésben, 2014-2018 közötti éves adatokból számítva (a teljes költségvetés =100\%)

Forrás: Európai Bizottság, DG Budget data alapján a szerző szerkesztése

A tárgyalások másik iránya lehet, ha a 2014-2020-as költségvetés Brexittel korrigált/ nem korrigált célszámaihoz a tagállami GNI 1\%-os hozzájárulás felett plusz befizetésben állapodnak meg a tagállamok a klímasemlegesség finanszírozására. Ez az opció abból a szempontból tűnhet reálisabbnak, hogy lehetőség nyílik egy ambiciózus, európai klímafinanszírozási rendszer kialakítására. A fent leírt okok miatt a kohéziós forrásokból nagy mértékben részesülő tagállamok minden olyan javaslatot támogatnak, amelyek a GNI-alapú tagállami befizetéseket növelik, vagy azokon felül biztosítanak plusz forrást, tekintve, hogy a nettó kedvezményezett országok részére folyósított összeg magasabb lesz, mint az általuk a költségvetésbe befizetett tétel. A nettó befizető tagállamok 
viszont igyekeznek a befizetéseiket a lehető legalacsonyabban tartani, ami lényegében visszavezet a jelenleg feloldhatatlannak látszó ellentétekhez a tagállamok között. (Haas-Rubio, 2017)

Az Európai Parlament még 2018-ban kiadta iránymutatását és véleményét az új többéves pénzügyi keret tárgyalására, amelyben hangsúlyozta, hogy az EU-nak új saját bevételt kell bevezetnie például a kibocsátás-kereskedelmi rendszer alapján egyfajta „karbonadó” vagy a digitális ágazatban tevékenykedő nagy cégek megadóztatása révén. Emellett pedig a Parlament 1,3\%-os tagállami GNI-hozzájárulást tartana szükségesnek a megfelelő költségvetés kialakításához, amely még a korábbi, Jean-Claude Juncker vezette Bizottság által javasolt 1,1\%-os küszöbnél is magasabb. (Európai Parlament 2018a, 2018b) Mindenbből jól látható, hogy nemcsak a tagállamok, de az EU intézményei között sincs egyetértés a következő költségvetés prioritásait és főösszegét illetően.

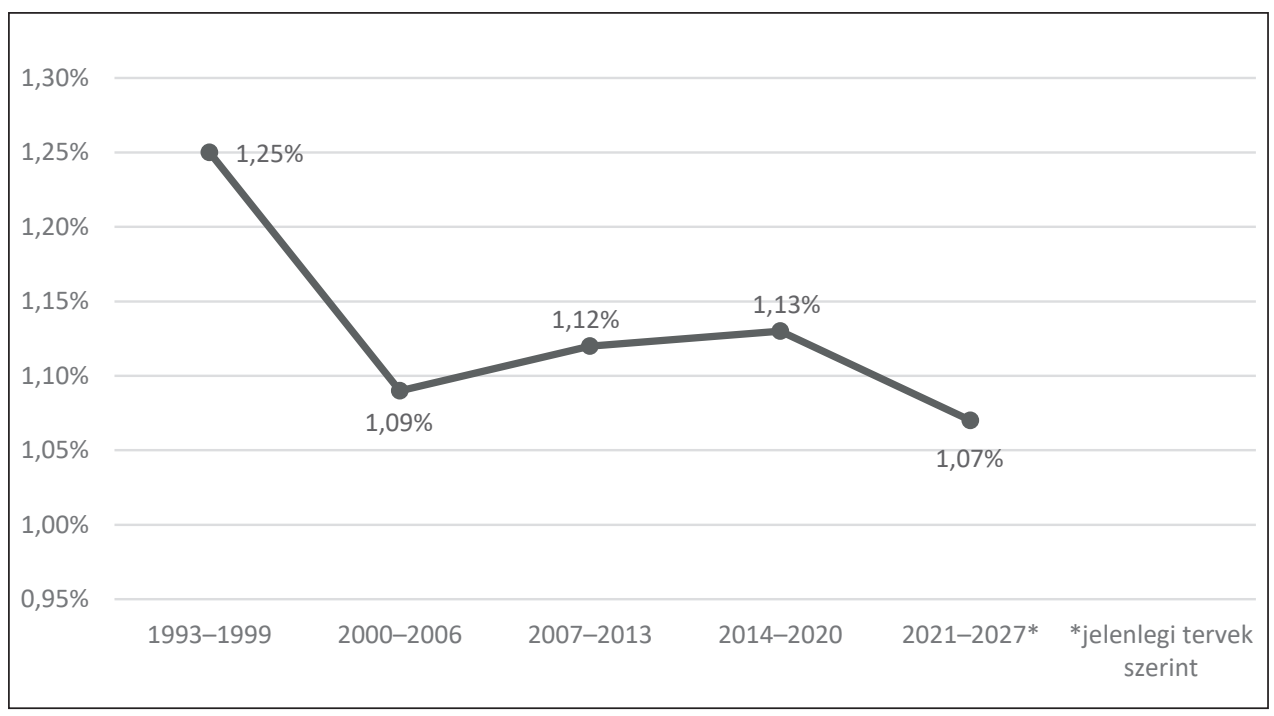

2. ábra

A tagállami GNI-hozzájárulás mértéke az unió többéves pénzügyi kereteihez, százalékban kifejezve

Forrás: Európai Bizottság, 2018a

A 2019 második félévében tanácsi elnökségét ellátó Finnország célul tűzte ki az MFF-tárgyalások előremozdítását. 2019. december 5-én az elnökség kiadott egy a 2021-2027-es költségvetésre vonatkozó tárgyalási keretet, úgynevezett negotiation boxot, amelyben a tagállami GNI-hozzájárulást 1,07\%-ban határozta meg. A javaslat hét költségvetési fejezetet tartalmaz. (Európai Unió Tanácsa, 2019) 


\section{1. táblázat}

Az unió többéves pénzügyi kereteinek fejezetei a 2007-2013-as és 2014-2020-as költségvetés, valamint a 2021-2027-re vonatkozó finn tervezet alapján

\begin{tabular}{|c|l|l|l|}
\hline $\begin{array}{c}\text { Költségvetési } \\
\text { időszak }\end{array}$ & \multicolumn{1}{|c|}{$\mathbf{2 0 0 7 - 2 0 1 3}$} & \multicolumn{1}{|c|}{$\mathbf{2 0 1 4 - 2 0 2 0}$} & $\begin{array}{c}\text { 2021-2027 } \\
\text { (a finn elnökség tervei } \\
\text { alapján) }\end{array}$ \\
\hline \multirow{5}{*}{ Fejezetek } & Fenntartható növekedés & $\begin{array}{l}\text { Intelligens és inkluzív } \\
\text { növekedés }\end{array}$ & $\begin{array}{l}\text { Egységes piac, innováció } \\
\text { és digitalizáció }\end{array}$ \\
\cline { 2 - 5 } & $\begin{array}{l}\text { A természeti erőforrások } \\
\text { kezelése és megörzése }\end{array}$ & $\begin{array}{l}\text { Fenntartható növekedés: } \\
\text { természeti erőforrások }\end{array}$ & Kohézió és értékek \\
\cline { 2 - 5 } & $\begin{array}{l}\text { Állampolgárság, } \\
\text { szabadság, biztonság } \\
\text { és a jog érvényesülése }\end{array}$ & $\begin{array}{l}\text { Biztonság és uniós } \\
\text { polgárság }\end{array}$ & $\begin{array}{l}\text { Természeti erőforrások } \\
\text { és környezet }\end{array}$ \\
\cline { 2 - 5 } & $\begin{array}{l}\text { Az EU mint globális } \\
\text { szerepló }\end{array}$ & Globális Európa & $\begin{array}{l}\text { Migráció } \\
\text { és határigazgatás }\end{array}$ \\
\cline { 2 - 5 } & Igazgatás & Igazgatás & Biztonság és védelem \\
\cline { 2 - 5 } & Kompenzáció & Kompenzáció & $\begin{array}{l}\text { Szomszédságpolitika és } \\
\text { nemzetközi kapcsolatok }\end{array}$ \\
\cline { 2 - 4 } & & & Európai adminisztráció \\
\hline
\end{tabular}

Forrás: Iván, 2006; Európai Unió Tanácsa, 2013; Európai Unió Tanácsa, 2019 alapján a szerző szerkesztése

$\mathrm{Az}$ 1. táblázatban látható, hogy a keretjavaslat bizonyos változtatásokkal ugyan, de követi a korábbi MFF főfejezeteinek struktúráját. Az szintén kiderül a javaslatból, hogy nem képezne külön fejezetet a klímasemlegesség finanszírozása, azt a finn elnökség a harmadik fejezetbe illesztené be. A harmadik fejezet két pillére a KAP és a vidékfejlesztés, a környezetvédelem és klímaambíciók finanszírozása pedig a KAP mellé kerülne. (Európai Unió Tanácsa, 2019) Ez több szempontból is problémát jelent, hiszen a kiterjedt mezőgazdasági szektorral rendelkező tagállamok számára nem járható út a Brexit miatt amúgy is csökkenő agrárkifizetések további megvágása, arról nem is beszélve, hogy ez az opció nem irányozna elő a hagyományos alapokon kívüli, a klímasemlegességre fordítható plusz EU-s forrásokat sem. Mindehhez azonban hozzá kell tennünk, hogy mivel a finnek hagyományosan ellenzik a tagállami befizetések növelését, nem volt céljuk egy ambiciózus büdzsé kitárgyalása az elnökség alatt. A 2019 decemberében megtartott európai tanácsi csúcson látszólag nem közeledtek a tagállami álláspontok sem a fent javasolt fejezeteket, sem a főösszeget illetően. A 2020. február 20-i Európai Tanácson szintén nem született megállapodás, majd a márciusi csúcson elsősorban a koronavírussal összefüggő problémák kerültek előtérbe.

A fentiekből arra következtethetünk, hogy az MFF tárgyában három fő kérdéskörben szükséges a tagállamoknak megállapodásra jutniuk:

1. a tagállami GNI-alapú befizetések nagysága;

2. a költségvetési keret szerkezete, különös tekintettel a klímasemlegesség finanszírozására;

3. új saját forrás kialakítása a bevételi oldalon, lehetőség szerint a fenntarthatósági szempontok figyelembevételével. 
A fentiek mellett érdemes megemlíteni, hogy az Európai Parlament és a Bizottság is előirányozta a központi irányítású programok, mint amilyen az Erasmus vagy a Horizon Europe forrásainak megemelését. A közép-európai, illetve 2004 után csatlakozott államok részvételének aránya azonban ezekben a programokban jóval a hozzájárulásuk alatt van. Ezt jól alátámasztja, hogy az EU 13-ak a 2014-2020-as időszakban a Horizon Europe forrásainak mindössze 10,8\%-át nyerték el, míg az EU 15-ök a 78\%-át. (Európai Bizottság, 2019c) A programok az elmaradott tagállamok számára is lehetőséget jelentenének a versenyképesség szempontjából az európai és globális innovációs vérkeringésbe való bekapcsolódáshoz, ehhez azonban a tagállami részesedésük növelése elengedhetetlen. Ezt elősegítheti a tagállami szinten jobban megszervezett pályázati rendszer a sikerességi ráta növelése érdekében, Magyarország esetében esetleg egy V4-es projektalapú koordináció, illetve nemzeti minimumtámogatási keretek meghatározása a központi irányítási programokban.

Ami a fentiekből jól látható, hogy az MFF-tárgyalások igencsak késésben vannak, megállapodás pedig egyelőre nincs kilátásban. A 2020-ban első tanácsi elnökségét betöltő Horvátország az elnökségi programjában egy ambiciózus költségvetés kitárgyalását célozza meg. A finn megközelítés után tehát egy nemrég csatlakozott, kelet-európai tagállam kap lehetőséget a tárgyalások előmozdítására. (Croatian Presidency of the Council of the European Union, 2019) Fontos azonban, hogy a COVID-19 járvány megjelenésével és kezelésével kapcsolatban az EU gyors és hatékony fellépése vált szükségessé. Mindez előrevetíti, hogy az MFF véglegesítése a német elnökség feladata lesz 2020 második félévében. (Schulz, 2020) A tagállamok eltérő prioritásai mellett nagy a nyomás az új Bizottságon, hogy egy olyan költségvetést alakítson ki, amely alkalmas a klímacélok finanszírozására. Ehhez kapcsolódik az Európai Zöld Megállapodásban már előirányzott, a Bizottság 2020 januárjában közzétett tervezete az Igazságos Átmenet Mechanizmusról, amely egy három pillérből álló, a klímasemlegességre való átállást finanszírozó komplex mechanizmus. (Európai Bizottság, 2020a)

\section{A fenntarthatóság finanszirozásának gazdasági lehetőségei az EU-ban - a Just Transition Mechanism (JTM)}

A Just Transition Mechanism, magyarul Igazságos Átmenet Mechanizmusnak fordított javaslat megjelenését nagy várakozások előzték meg, mivel Ursula von der Leyen már jelöltsége idején is hivatkozott az akkor még egyfajta klímafinanszírozási alapként leírt javaslatcsomagra. A Bizottság végül 2020. január 14-én tette közzé a hivatalos tervezetét, amelyet a tagállamok ezt követően több tanácsülésen és a 2020. február 20-i Európai Tanács ülésén is megvitattak. A Bizottság közleménye szerint az alap célja, hogy hozzájáruljon a fosszilis tüzelőanyagoktól vagy energiaigényes iparágaktól leginkább függő és emiatt az átállás által leginkább érintett régiókban és ágazatokban jelentkező társadalmi-gazdasági hatás enyhítéséhez. (Európai Bizottság, 2020a, 2020b)

A javaslat szerint a Mechanizmus három pillérből állna, s a tervek szerint legalább 100 milliárd euró forrást csatornázna be a fenntartható gazdaságra történő átállás folyamatába. Az első pillér maga az Igazságos Átmenet Alap, egy pénzügyi alap, 
amely 2018-as árakon számolva 7,5 milliárd euró forrást jelentene. A 7,5 milliárd eurót tagállamonként osztotta el a Bizottság, a legnagyobb kedvezményezett Lengyelország és Németország, míg Magyarország az elmúlt évek alatt teljesített nagymértékú szén-dioxid-kibocsátás csökkentése ellenére is mindössze 92 millió eurót, a teljes keret 1,2\%-át kapná meg. A tagállami allokációs adatokat NUTS 2 szintre lebontva, több elem figyelembevételével számították ki. A kiadott módszertan szerint a végső nemzeti allokációkat az alábbi paraméterek figyelembevételével határozták meg: az ipari létesítmények üvegházhatású gázkibocsátásának aránya azokban a régiókban, ahol e kibocsátások szén-dioxid-intenzitása meghaladja az uniós átlagot, ezen ipari létesítményekben és a szén- és lignitbányászatban foglalkoztatottok súlya az adott ország foglalkoztatási statisztikájában, valamint a tőzeg- és olajpala-termelés országonkénti aránya. Az így kapott adatokat még korrigálták annak a számadatnak a másfélszeresével, hogy az adott tagállam 2015-2017 közötti GNI (PPP) aránya mennyivel tér el az EU átlagától. Megállapították továbbá, hogy az alapból 2 milliárd eurónál többet nem kaphat egy tagállam sem, valamint a 6 euró/fő alatti népességarányos támogatás is kizárt. Mindezek mellett fontos, hogy az így kapott forrásokat a tagállamoknak ki kell egészíteniük az Európai Regionális Fejlesztési Alap (ERFA) és/vagy az Európai Szociális Alap+ (ESZA+) kereteik terhére, amelyekhez még 20-30\%-os arányban nemzeti társfinanszírozást is biztosítaniuk kell. (Európai Bizottság 2020b, 2020c) Jól látható tehát, hogy a Bizottság az alapot inkább csak a klímafinanszírozás katalizátoraként vetné be, az ehhez szükséges források nagyobb részét a költségvetés vonatkozó fejezetei és a tagállami vállalások biztosítanák.

A 3. ábra szemlélteti a Mechanizmus tagállamonkénti allokációját euróban, amelyet összevetettem az egy főre jutó összegekkel szintén euróban, tagállamonként. Ebből jól látható, hogy Lengyelország részesül a legnagyobb mértékben a forrásokból, hiszen a maximális 2000 millió eurót kaphatja meg, míg a legkisebb összeg - nem meglepő módon - Luxemburgé, minössze 4 millió euróval. Az allokációs számoknál ugyanakkor többet mond az Igazságos Átmenet Alap fent már röviden ismertetett módszertana és az egy főre jutó összegek vizsgálata. Az elvégzett számításaimból jól látszik, hogy az egy főre jutó összeg Észtországban, Bulgáriában és Csehországban a legnagyobb, míg a legkisebb minimális 6 eurós határ olyan fejlett országoknál jelenik meg, mint Belgium, Dánia vagy Írország. Magyarország szempontjából érdemes megvizsgálni, hogy tulajdonképpen mind a másik három V4-ország, mind a szomszédos országok két számjegyú egy főre jutó allokációs arányokkal számolhatnak, szemben a Magyarországra jutó 9 euróval. Szintén érdekes, hogy Magyarországon a Bizottság módszertana szerint nincsenek szén- és lignitbányászatban dolgozó munkavállalók, míg a másik három V4-országban ez rendre megjelenik a számításban. (Európai Bizottság 2020c) Ezt a problémát azért is nagyon fontos kiemelni, mert ugyan az egyértelmű, hogy az egyes országokban nem azonos a szénbányászat termelése és az ágazatban foglalkoztatottak száma, azonban a Bizottság Közös Kutatóközpontjának európai szénbányászatról szóló elemzése is rámutat arra, hogy a Magyarországon működő két szénbánya az európai széntermelés 2\%-át adja. A Magyarországnál kisebb Szlovénia egy múködő bányája az európai össztermelés 0,6\%-át termeli ki, esetükben mégis feltüntették a Bizottság által közzétett Igazságos Átmenet Alap allokációs táblázatában a kétezer foglalkoztatottat. (Európai Bizottság 2018b) Magyarországnál az Alap forrásainak elosztásánál tehát nem vették figyelembe a még működő szénbányákat, így a foglalkoztatottak számát sem. 
A vizsgálat alapján talán nem megalapozatlan a tanulmány felvetése, miszerint a Mechanizmussal a Bizottság szándéka lehet az Ambiciózus Európa költségvetése országcsoport megosztása, így Lengyelország, Csehország, Szlovákia és - nagy népessége, így szavazati súlya révén - esetleg Románia számára kedvezőbb feltételek biztosítása, így mozgásterük növelése a költségvetési tárgyalások során. Hivatalos adatok ugyan még nincsenek a 2021-2027-es költségvetés tagállami allokációs számairól, de a 2014-2020-as költségvetés országonkénti, kohéziós alapokból való részesedési arányait vizsgálva azt láthatjuk, hogy a kohéziós forrásokból legnagyobb mértékben részesülő országok Lengyelország, Magyarország, Románia és Csehország. A 2004 után csatlakozott tagállamok közül pedig a KAP-ban is ez a négy ország érintett a legnagyobb mértékben. (European Court of Auditors, 2019) Így tehát a kohéziós források és a KAP főösszegének nagyobb arányú megvágása esetén az Igazságos Átmenet Alap néhány százalékos kompenzációt jelenthet ezen országok számára. Természetesen az, hogy ezt a lehetőséget mennyire tudják kihasználni a tagállamok, csak a letárgyalt MFF-számok tükrében állapítható majd meg bizonyossággal, ugyanakkor ez is jól mutatja, hogy a fenntarthatóság finanszírozásának kérdése döntő befolyással van az egész költségvetési keret tárgyalására.

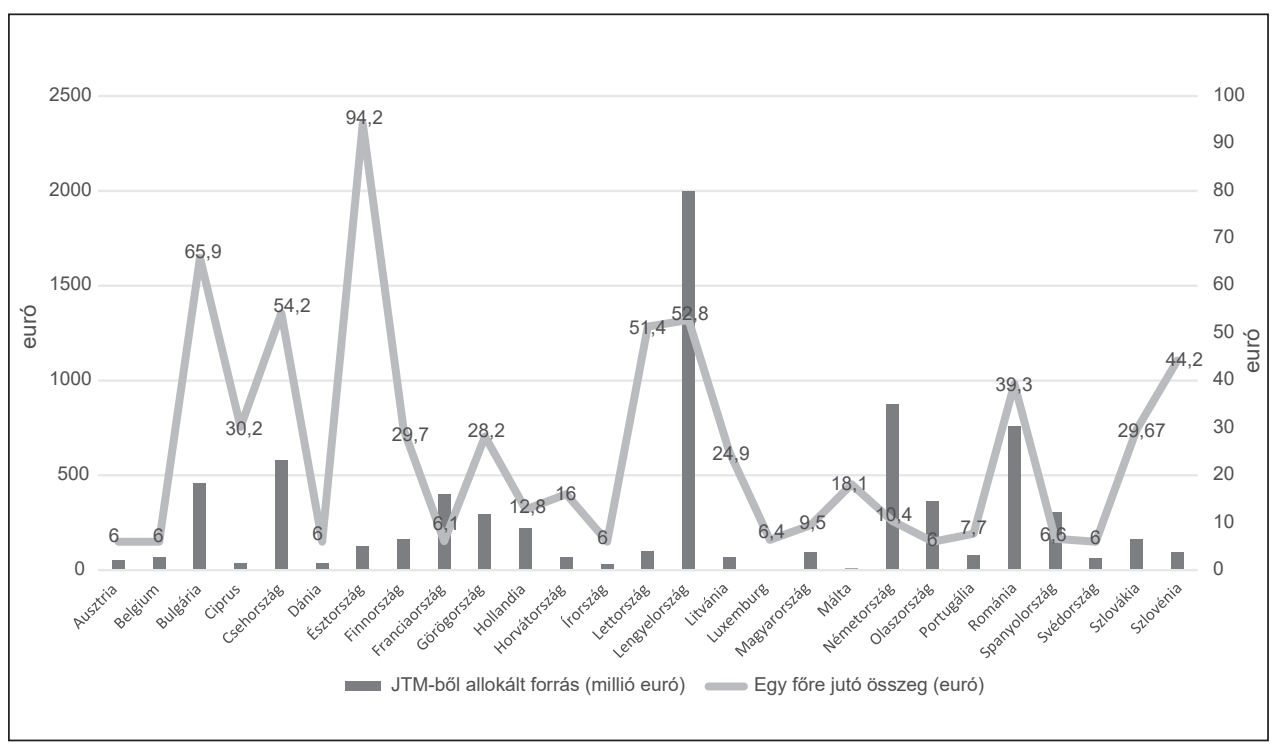

3. ábra

Az Igazságos Átmenet Mechanizmusból allokált összegek és az egy före jutó összegek tagállamonként (az egy före jutó összegek számmal jelölve)

Forrás: Európai Bizottság 2020a, 2020b, 2020c és a Világbank demográfiai adatai alapján a szerző számolása és szerkesztése 
Az Igazságos Átmenet Mechanizmus második és harmadik pillére nagyban összefügg. A második pillért az InvestEU-n belül létrehozandó Igazságos Átmenet fejezet jelenti, amelytől nagyságrendileg 45 milliárd eurónyi magánbefeketetés mobilizálását várják. Ez tulajdonképpen egy hitelkeret lenne, amellyel a „zöld” magánbefektetéseket támogatnák. Míg a harmadik pillér az Európai Beruházási Bank Eszköz kifejezetten a közszféra és a helyi önkormányzatok fenntartható projektjeinek támogatására kialakított hitelkeret. Utóbbitól 25-30 milliárd eurónyi közpénzt megmozgató befektetéseket várnának. A második és harmadik pilléren belül lesznek tehát támogathatók a megújuló energiára és energiahatékonyságra épülő infrastruktúra-beruházások, az energia és közelekedési-szállítási infrastruktúra-fejlesztés és egyéb dekarbonizációs projektek is. (Európai Bizottság, 2020a)

A Mechanizmus teljes egészében illeszkedik a Bizottság által közzétett Fenntartható Európa beruházási terv keretrendszerébe, amely tulajdonképpen az Európai Zöld Megállapodás pénzügyi háttere. Jól látható, hogy a Bizottság a 2021-2030-as időtartam alatt 1000 milliárd euró magán- és közbefektetés mozgósítását tervezi. (Európai Bizottság, 2020d)

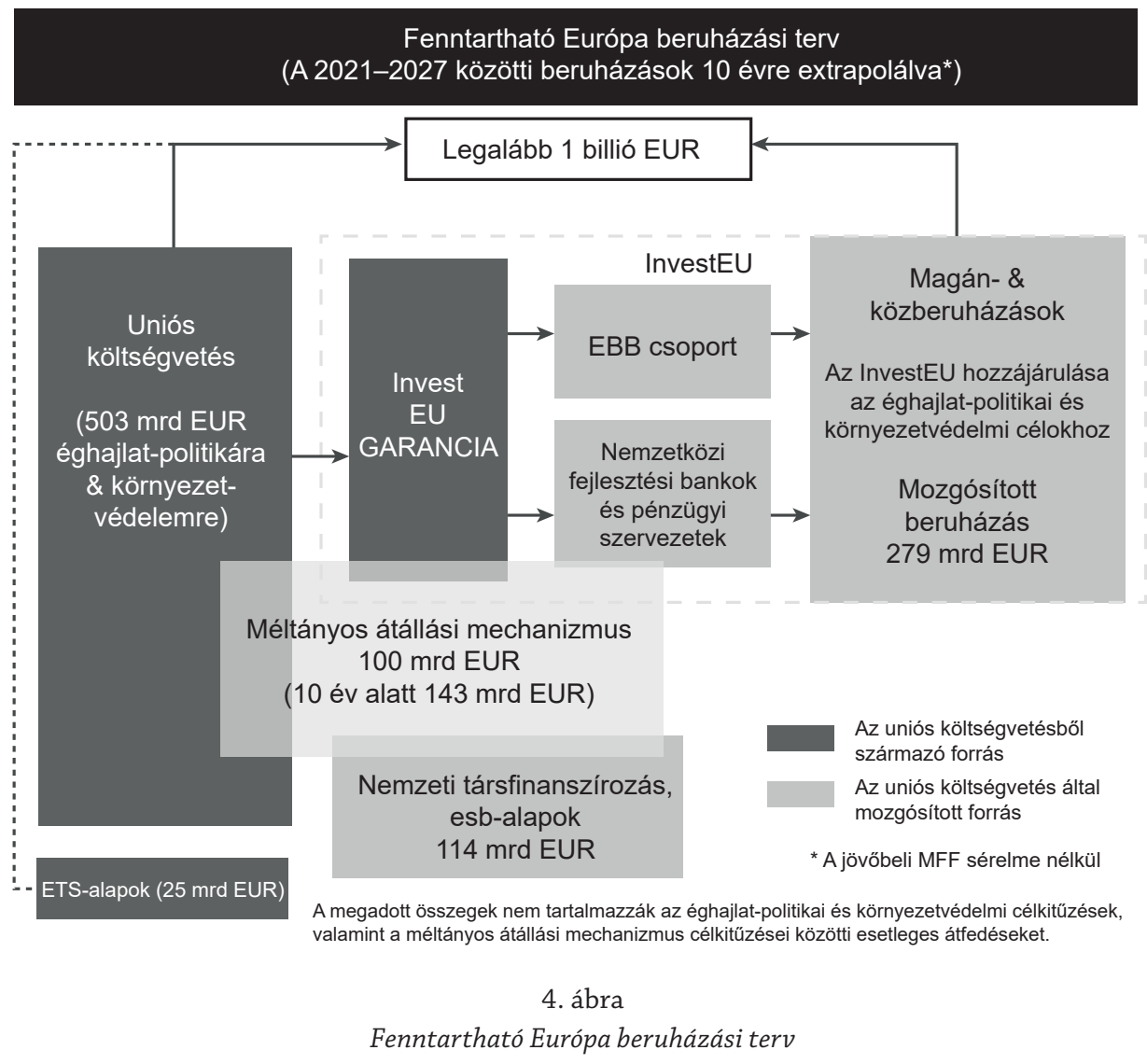

Forrás: Európai Bizottság, 2020d 
Az Igazságos Átmenet Mechanizmus „igazságos” és „átmenet” voltát is számos tagállam megkérdőjelezi. A fent ismertetett módszertani háttér mellett számos tagállam számára problémát jelent, hogy az Alap által biztosított források nem használhatóak fel nukleáris erőművek építésére/leszerelésére és fosszilis üzemanyagok égetéséhez, termeléséhez, feldolgozásához köthető beruházásokhoz sem, míg támogatható belőle általánosságban a munkaerőképzés, a körforgásos gazdasággal kapcsolatos befektetések, kutatási tevékenységek. (Európai Bizottság 2020e) Vagyis az Igazságos Átmenet Alap támogatható tevékenységeinek a köre igen hasonló a Kohéziós Politika céljaihoz, és az energiaátmenet helyett inkább az átállást követő alkalmazkodási időszak befektetéseihez ad támogatást. Az ismertetett második és harmadik pillér forrásainak felhasználási köre ugyan tágabban határozza meg a támogatható beruházások fajtáit, de nem szabad szem elől tévesztenünk, hogy ez a két pillér az Alappal szemben hitel. Kérdéses, hogy ilyen keretek között mennyire tudja kihasználni a forrásokat például a számos szénbányával rendelkező Lengyelország vagy az éppen nukleáris erőművet építő Magyarország és Csehország.

A tagállamoknak el kell készíteniük a saját területi igazságosátmenet-terveiket a nemzeti klímasemlegességre törekedve, megjelölve a Mechanizmus által biztosított források felhasználási területeit összhangban a kohéziós források lehívásához szükséges operatív programjaik prioritásaival. A finanszírozáshoz jutás feltétele a nemzeti tervek Bizottság általi jóváhagyása. A Bizottság ütemezése szerint a tagállamoknak már most el kell kezdeniük a tervek elkészítését, mert 2021-ben szeretné, ha működésbe lépne az Igazságos Átmenet Mechanizmus. A Bizottság által közzétett javaslatcsomag szintén tartalmazza, hogy adott célindikátorok szerint folyamatosan ellenőrizni szükséges a tagállamok forrásfelhasználását. A tervezet 9. cikke felvillantja, hogy amennyiben a teljesítményértékelés alapján a kitúzött célok nem valósulnak meg legalább 65\%ban, az utólagos tagállami pénzügyi korrekciót vonhat maga után. (Európai Bizottság, 2020f) Az említett indikátorrendszer részletei és a támogatások esetleges csökkentésének vagy visszafizettetésének pontos szabályai viszont nem derülnek ki egyértelműen a dokumentumból.

Az Igazságos Átmenet Alap jó kezdeményezésnek tekinthető, hiszen az EU-s, valamint a köz- és magánbefektetések mobilizálásával együtt igyekszik támogatni a fenntarthatósági átmenetet. Számos tagállam azonban kevesli az alap főösszegét, arra hivatkozva, hogy 7,5 milliárd euró túl kevés erre a célra. A mechanizmus kétségkívül akkor lehet sikeres, ha a hitelkeretek révén valóban megindulnak a „zöld” befektetések mind az innováció, mind pedig az infrastruktúra területén. Mivel azonban az Igazságos Átmenet Mechanizmus sem tud a tagállamok tamogatása nélkül hatékonyan működni, a Bizottságnak elsősorban arról kell meggyőznie a tagállamokat, hogy a szóban forgó 7,5 milliárd euró valóban „plusz pénz”, és azt nem a tárgyalás alatt lévő többéves pénzügyi keret KAP keretéből vagy az egyébként a Mechanizmus mellé rendelt kohéziós alapokból történő átcsoportosítással próbálják előteremteni. 


\section{Összefoglalás}

A tanulmányban rávilágítottunk arra, hogy az Európai Unió prioritásként kezeli a környezetvédelemmel és fenntarthatósággal kapcsolatos kérdések megoldását. Az Európai Zöld Megállapodás igen ambiciózus ötletgyüjtemény a klímasemleges európai kontinens elérése érdekében. Ugyanakkor az is jól érzékelhető, hogy a klímafinanszírozás kérdésében nincs konszenzus a tagállamok között. Emellett pedig az Európai Zöld Megállapodásban foglalt tervek megvalósítása is számos kérdést vet fel, kiemelten a klímatörvény és a „karbonadóztatás” kidolgozását, megvalósítását illetően.

A 2021-2027-es költségvetési tárgyalásokkal kapcsolatban a tagállamoknak elsősorban azt kell eldönteniük, hogy mekkora legyen a GNI-alapú források nagysága, milyen fejezetbe kerüljenek a klímafinanszírozásra szánt összegek, amennyiben azokat az MFF-en belül szeretnék tartani a tagállamok, illetve nem utolsósorban arról is szükséges megállapodás, hogy milyen új bevételi forrás fogadható el a huszonhetek számára.

Az Igazságos Átmenet Mechanizmus elemzéséből arra a következtetésre jutottunk, hogy a Bizottság mechanimzusa mindinkább csak egyfajta katalizátora lesz a klímasemlegesség finanszírozásának, hiszen a 7,5 milliárd eurós alap három pillére közel sem nyújt elegendő forrást minden tagállam számára. Ugyanakkor a tagállami allokációs adatok és az Igazságos Átmenet Mechanizmus módszertanának vizsgálatát követően azonosíthatók olyan tagállamok (kiemelten Lengyelország, Csehország, Románia), akik az Igazságos Átmenet Mechanizmusban lévő kedvező helyzetük révén, a költségvetési tárgyalások során, várhatóan könyebben kompromisszumot köthetnek majd.

A kutatás további szakaszában érdemes követni a költségvetési tárgyalások menetét és a Bizottság kommunikációját, hiszen a tanulmányban felvetett kérdések csak a letárgyalt költségvetési számokkal válaszolhatóak meg kétségtelenül.

Egyértelmű, hogy olyan globális kihívások közepette, mint a COVID-19 járvány vagy az amerikai-kínai kereskedelmi háború, a költségvetési tárgyalások befejezése nem kis kihívás az Európai Unió számára. Az elkövetkezendő években azonban el kell döntenie az öreg kontinens tagállamainak, hogy mennyire elkötelezettek valójában a fenntarhatóság mellett, és hogyan tudnak ebből az európai polgárok is a legnagyobb és legegyenlőbb mértékben részesülni.

\section{Felhasznált irodalom}

BARANYAi Gábor - CSERnus Dóra Ildikó szerk. (2019): A fenntartható fejlődés és az állam. Budapest, Dialóg Campus Kiadó.

Boldizsár Anna - KéKesi Zsuzsa - KoroknAi Péter - SisAK Balázs (2016): A magyarországi EU-transzferek áttekintése - két költségvetési korszak határán. Hitelintézeti Szemle, 15. évf. 2. sz. 59-87.

IVÁN Gábor (2006): Az Európai Unió pénzügyi keretterve 2007-2013-ra - az infúzió bekötve. Közgazdasági Szemle, 53. évf. 5. sz. 428-451.

KNOLL Imre - LAKATOS Péter szerk. (2014): Közszolgálat és fenntarthatóság. Budapest, Nemzeti Közszolgálati Egyetem. 
Lightfoot, Simon - Burchell Jon (2005): The European Union and the World Summit on Sustainable Development: Normative Power Europe in Action? Journal of Common Market Studies, Vol. 43, No. 1. 75-95. DOI: https://doi.org/10.1111/j.00219886.2005.00547.x

Murray, Joy - DeY, Christopher (2009): The carbon neutral free for all. International Journal of Greenhouse Gas Control, Vol. 3, No. 2. 237-248. DOI: https://doi.org/10.10 16/j.ijggc.2008.07.004

PAlÁNKai Tibor - Kengyel Ákos - KutAsi Gábor - Benczes István - NAgy Sándor Gyula (2011): A globális és regionális integráció gazdaságtana. Budapest, Akadémiai Kiadó. DOI: https://doi.org/10.1556/9789630598385

\section{Internetes források}

Az Európai Parlament és a Tanács 2003. október 13-i 2003/87/EKirányelve az üvegházhatást okozó gázok kibocsátási egységei Közösségen belüli kereskedelmi rendszerének létrehozásáról és a 96/61/EK tanácsi irányelv módosításáról. Elérhető: https://eurlex.europa.eu/LexUriServ/LexUriServ.do?uri=CONSLEG:2003L0087:20041113:HU:PDF (A letöltés ideje: 2020. 04. 10.)

Az Európai Parlament és a Tanács 2008. május 21-i 2008/50/EK irányelve a környezeti levegő minőségéről és a Tisztább levegőt Európának elnevezésű programról. Elérhető: https://eur-lex.europa.eu/legal-content/HU/TXT/HTML/?uri=CELEX:32008 L0050\&from=hu (A letöltés ideje: 2020. 04. 10.)

Az Európai Parlament és a Tanács 2008. november 19-i 2008/98/EK irányelve a hulladékokról és egyes irányelvek hatályon kívül helyezéséről. Elérhető: https://eur-lex. europa.eu/legal-content/HU/TXT/?uri=celex:32008L0098 (A letöltés ideje: 2020. 04. 10.)

Az Európai Parlament és a Tanács 2013. november 20-i 1386/2013/EU határozata a „Jólét bolygónk felélése nélkül” címú, a 2020-ig tartó időszakra szóló általános uniós környezetvédelmi cselekvési programról. Elérhető: https://eur-lex.europa. eu/legal-content/HU/TXT/HTML/?uri=CELEX:32013D1386\&from=EN (A letöltés ideje: 2020. 04. 10.)

CĂtuți, Mihnea - Elkerbout, Milan (2019): The opportunities of the Modernisation Fund for the energy transition in Central and Eastern Europe. CEPS Policy Insights, Vol. 18, No. 9. Elérhető: www.ceps.eu/wp-content/uploads/2019/06/PI2019_09_ Modernisation_Fund_Paper.pdf (A letöltés dátuma: 2020. 04. 10.)

BARBIÈRe, Cécile (2019): Not all member states will benefit from the European Green Deal. Euractiv, 15. 01. 2020. Elérhető: www.euractiv.com/section/energy/news/notall-member-states-will-benefit-from-the-european-green-deal/ (A letöltés dátuma: 2020. 04. 10.)

Croatian Presidency of the Council of the European Union (2019): A strong Europe in a world of challenges - Programme of the Coratian Presidency. Elérhető: https://vlada. gov.hr/UserDocsImages/Vijesti/2019/12\%20prosinac/31\%20prosinca/web_ FINAL_PROGRAMME_EN_FINAL.pdf (A letöltés dátuma: 2020. 04.10.)

Európai Tükör 2020/1. 
D’Alfonso, Alessandro (2019): Mainstreaming of climate action in the EU budget. European Parliamentary Research Service. Elérhető: www.europarl.europa.eu/RegData/ etudes/IDAN/2019/642239/EPRS_IDA(2019)642239_EN.pdf (A letöltés dátuma: 2020. 04. 10.) DOI: https://doi.org/10.2861/469

ERFORTH, Benedikt - KEIJZER Niels (2020): EU budget summit: Is the EU risking another 'no deal'? Euractiv, 18. 02. 2020. Elérhető: www.euractiv.com/section/economy-jobs/ opinion/eu-budget-summit-is-the-eu-risking-another-no-deal/ (A letöltés dátuma: 2020. 04. 10.)

Európai Bizottság, DG budget data. Elérhető: https://ec.europa.eu/budget/graphs/revenue_expediture.html (A letöltés dátuma: 2020. 04. 10.)

Európai Bizottság (2018a): A modern EU budget for a Union that protects, empowers and defends. Elérhető: https://ec.europa.eu/commission/sites/beta-political/files/budgetproposals-modern-eu-budget-may2018_en.pdf (A letöltés dátuma: 2020. 04. 10.)

Európai Bizottság (2018b): EU coal regions: opportunities and challenges ahead. Elérhető: https://ec.europa.eu/jrc/en/publication/eur-scientific-and-technical-research-reports/eu-coal-regions-opportunities-and-challenges-ahead (A letöltés dátuma: 2020. 04. 10.) DOI: https://doi.org/10.2760/064809

Európai Bizottság (2018c): A müanyagok körforgásos gazdaságban betöltött szerepével kapcsolatos európai stratégia. Elérhető: https://eur-lex.europa.eu/legal-content/HU/ TXT/HTML/?uri=CELEX:52018DC0028\&from=EN (A letöltés dátuma: 2020. 04. 10.)

Európai Bizottság (2019a): Approval of the European Commission 2019-2024. Elérhető: https://ec.europa.eu/info/election-european-commission-2019-2024_en (A letöltés dátuma: 2020. 04. 10.)

Európai Bizottság (2019b): The European Green Deal. Elérhető: https://eur-lex.euro pa.eu/ legal-content/EN/TXT/?qid=1576150542719\&uri=COM\%3A2019\% 3A640\%3AFIN (A letöltés dátuma: 2020. 04. 10.)

Európai Bizottság (2019c): From Horizon 2020 to Horizon Europea monitoring flash. Elérhető: https://ec.europa.eu/info/sites/info/files/research_and_innovation/knowledge_ publications_tools_and_data/documents/h2020_monitoring_flash_022019.pdf (A letöltés dátuma: 2020. 04. 10.)

Európai Bizottság (2020a): The Just Transition Mechanism: Making Sure No One Is Left Behind. DOI: https://doi.org/10.2775/19010

Európai Bizottság (2020b): Allocation method for the Just Transition Fund. Elérhető: https://ec.europa.eu/commission/presscorner/detail/en/qanda_20_66 (A letöltés dátuma: 2020. 04. 10.)

Európai Bizottság (2020c): JTM and JTF allocation table. Elérhető: https://ec.europa.eu/ commission/presscorner/detail/en/qanda_20_66 (A letöltés dátuma: 2020. 04.10.)

Európai Bizottság (2020d): Commission Communication on the European Green Deal Investment Plan. Elérhető: https://ec.europa.eu/commission/presscorner/detail/en/fs_2 0_48 (A letöltés dátuma: 2020.04. 10.)

Európai Bizottság (2020e): A zöld gazdaságra való átállás finanszírozása: az Európai Zöld Megállapodáshoz kapcsolódó beruházási terv és a méltányos átállási mechanizmus Sajtóközlemény. Elérhető: https://ec.europa.eu/commission/presscorner/detail/hu/ ip_20_17 (A letöltés dátuma: 2020.04.10.) 
Európai Bizottság (2020f): Proposal for a regulation of the European Parliament and of the Council establishing the Just Transition Fund. Elérhető: https://eur-lex.europa.eu/ legal-content/EN/TXT/?uri=CELEX\%3A52020PC0022 (A letöltés dátuma: 2020. 04. 10.)

Európai Parlament (2018a): Hosszú távú uniós büdzsé: a Parlament pénzügyi prioritásai a 2020 utáni időszakra - Sajtóközlemény. Elérhető: www.europarl.europa.eu/news/ $\mathrm{hu} /$ press-room/20181106IPR18317/mff-a-parlament-penzugyi-prioritasai-a2020-utani-idoszakra (A letöltés dátuma: 2020. 04. 10.)

Európai Parlament (2018b): European Parliament resolution of 14 November 2018 on the Multiannual Financial Framework 2021-2027 - Parliament's position with a view to an agreement. Elérhető: www.europarl.europa.eu/doceo/document/TA-8-2018-0449_ EN.html?redirect (A letöltés dátuma: 2020. 04. 10.)

Európai Parlament (2019): Future financing of EU policies. Elérhető: www.europarl.europa. eu/RegData/etudes/BRIE/2019/635545/EPRS_BRI(2019)635545_EN.pdf (A letöltés dátuma: 2020. 04. 10.)

Európai Tanács (2019): Az Európai Tanács ülése (2019. december 12.) - Következtetések. Elérhető: www.consilium.europa.eu/media/41781/12-euco-final-conclusions-hu.pdf (A letöltés dátuma: 2020. 04. 10.)

Európai Unió Tanácsa (2013): A Tanács 1311/2013/EU, Euratom rendelete (2013. december 2.) a 2014-2020-asidőszakravonatkozótöbbéves pénzügyikeretröl. Elérhető: https:// eur-lex.europa.eu/legal-content/hu/TXT/PDF/?uri=CELEX:32013R1311\&from=EN (A letöltés dátuma: 2020. 04.10.)

Európai Unió Tanácsa (2016): Javaslat - Az Európai Parlament és a Tanács irányelve a 2003/87/EK irányelvnek a költséghatékony kibocsátáscsökkentés és az alacsony széndioxid-kibocsátású technológiákba történő beruházások növelése érdekében történô módosításáról - Irányadó vita. Elérhető: https://data.consilium.europa.eu/doc/document/ ST-9719-2016-INIT/hu/pdf (A letöltés dátuma: 2020. 04. 10.)

Európai Unió Tanácsa (2019): Multiannual Financial Framework (MFF) 2021-2027: Negotiating Box with figures. Elérhető: www.consilium.europa.eu/media/41630/st14518re01-en19.pdf (A letöltés dátuma: 2020. 04. 10.)

European Court of Auditors (2019): Rapid case review Allocation of Cohesion policy funding to Member States for 2021-2027. Elérhető: www.eca.europa.eu/lists/ecadocuments/ rcr_cohesion/rcr_cohesion_en.pdf (A letöltés dátuma: 2020. 04. 10.)

HAAS, Jörg - RuBIo, Eulalia (2017): Brexit and the EU budget: Threat or opportunity? Jacques Delors Institute. Elérhető: https://institutdelors.eu/wp-content/uploads/ 2018/01/brexiteubudget-haasrubio-jdi-jan17.pdf (A letöltés dátuma: 2020. 04. 10.)

Ambiciózus Európához ambiciózus költségvetés kell (2020). Magyarország kormánya, 2020. 02. 21. Elérhető: www.kormany.hu/hu/a-miniszterelnok/hirek/ambiciozuseuropahoz-ambiciozus-koltsegvetes-kell (A letöltés dátuma: 2020. 04. 10.)

Schulz, Florence (2020): Linn Selle: Coronavirus may have a long impact on German presidency. Euractiv, 17. 03. 2020. Elérhető: www.euractiv.com/section/future-eu/ interview/linn-selle-coronavirus-may-have-a-long-impact-on-german-presidency/ (A letöltés dátuma: 2020. 04. 10.) 
Ursula von der Leyen as a candidate for the president of the European Comission (2019): Political Guidelines for the Next European Comission 2019 - 2024. Elérhető: https:// ec.europa.eu/commission/sites/beta-political/files/political-guidelines-next-commission_en.pdf (A letöltés dátuma: 2020. 04. 10.) 